\title{
Perbedaan critical thinking sistem kontrol elektromekanik dan elektronik menggunakan model pembelajaran discovery learning dibandingkan dengan model pembelajaran problem based learning di era industri 4.0 pada siswa kelas XI SMK Negeri 1 Singosari
}

\author{
Tiya Nurul Khusna, Syaad Patmanthara *, Dyah Lestari \\ Universitas Negeri Malang, Jl. Semarang No. 5 Malang, Jawa Timur, Indonesia \\ *Penulis korespondensi, Surel: syaad.ft@um.ac.id
}

Paper received: 03-01-2021; revised: 15-01-2021; accepted: 30-01-2021

\begin{abstract}
Abstrak berisi 150-200 kata dan hanya terdiri atas 1 paragraf, yang memuat latar belakang, tujuan, metode, serta hasil penelitian.
\end{abstract}

Keywords: kata kunci 1; kata kunci 2; kata kunci 3

\begin{abstract}
Abstrak
Pelaksanaan pembelajaran di era Revolusi Industri 4.0, guru berperan sebagai fasilitator dalam proses belajar mengajar. Tujuan dari pembelajaran tersebut agar siswa dapat meningkatkan kreatifitas dan keaktifan pada saat pembelajaran dengan saling berinteraksi secara aktif yang mengakibatkan proses dalam pembelajaran akan lebih efektif. Masalah proses belajar mengajar pada materi Sistem Kontrol Elektromekanik dan Elektronik (SKEE) umumnya terjadi di dalam kelas. Kegiatan mengajar harus memiliki model, teknik, dan strategi pembelajaran agar tercapainya tujuan yang telah direncanakan. Penelitian ini menggunakan 2 kelas eksperimen. Kelasbeksperimen A menggunakan model pembelajaran Discovery Learning. Kelasbeksperimen B menggunakan model pembelajaran Problem Based Learning. Rancangan penelitian ini menggunakan nilai KD sebelumnya dimana data ini digunakanbuntuk representasi awal critical thinking siswa dan posttestddigunakan sebagai hasil critical thinking siswa setelah diberikan eksperimen model pembelajaran. Hasil penelitian ini adalah siswa kelas eksperimen A memperoleh hasil nilai posttest critical thinking dengan rata-rata 80,76 yang termasuk kedalam kategori sangat tinggi. Siswa kelas eksperimen B memperoleh hasil nilai posttest critical thinking dengan rata-rata 85,12. Terdapat perbedaan yang signifikan antara kelas eksperimen A dengan kelas eksprimen B terhadap critical thinking siswa. Keunggulan penerapan model discovery learning siswa mampu menemukan pola belajar dengan caranya sendiri yang membuat kemampuan berpikir kritis meningkat. Keunggulan penerapan PBL siswa aktif dalam penyelesaian permasalahan yang membuat kemampuan berpikir kritis meningkat.
\end{abstract}

Kata kunci: critical thinking; discovery learning; problem based learning

\section{Pendahuluan}

Dalam pelaksanaan pembelajaran di era Revolusi Industri 4.0, guru berperan sebagai fasilitator dalam proses belajar mengajar. Tujuan dari pembelajaran tersebut agar siswa dapat meningkatkan kreatifitas dan keaktifan pada saat pembelajaran dengan saling berinteraksi secara aktif yang mengakibatkan proses dalam pembelajaran akan lebih efektif. Tingkat keberhasilan suatu pembelajaran dapat dilihat pada kualitas siswa yang memahami materi pembelajaran. Kesiapan dalam menghadapi Revolusi 
Industri 4.0 ini yang membuat siswa harus menguasai salah satu kemampuan yang ada pada Revolusi Industri 4.0. Hal tersebut menjadikan kuantitas bukanlah menjadi indikator utama dalam mencapai kesuksesan pembelajaran melainkan kualitas lulusannya. Kurikulum 2013 yang telah dikembangkan untuk menghadapi Revolusi Industri 4.0 memiliki karakteristik 4C yaitu Collaboration,Creative Skill, Communication dan Critical Thinking (Zaenal, 2017). Masalah proses pembelajaran pada materi sistem konrol elektromekanik dan elektronik umumnya terjadi di dalam kelas. Kegiatan mengajar harus memiliki model, teknik, dan strategi pembelajaran agar tercapainya tujuan yang telah direncanakan. Hasil pembelajaran SKEE di SMKN 1 Singosari progam keahlian Teknik Otomasi Industri belum maksimal disebabkan adanya penerapan model atau strategi dalam pembelajaran yang belum sesuai.

Pengamatan berlangsung selama kegiatan Kajian Praktik Lapangan (KPL) pada bulan Agustus tahun 2019 dengan guru Mata Pelajaran Sistem Kontrol Elektromekanik dan Elektronik di SMKN 1 Singosari. Mata Pelajaran SKEE termasuk dalam mata pelajaran produktif di SMK yang wajib ditempuh siswa jurusan Teknik Otomasi Industri (TOI). SKEE merupakan pembelajaran yang mempelajari alat-alat piranti kontrol, pengamanan, dan kondisi operasi seperti: (1) saklar; (2) relay; (3)

kontaktor; dan (4) inverter. Model pembelajaran yang digunakan oleh guru pengampu adalah discovery learning. Penerapan model pembelajaran discovery learning belum sepenuhnya sesuai dengan sintaksnya. Hal tersebut menyebabkan kemampuan critical thinking siswa pada pembelajaran SKEE kurang optimal. Hal ini dilihat dari hasil pekerjaan siswa yang belum mengarah pada cara berpikir kritis.

Era Revolusi Industri 4.0 merupakan suatu hal yang harus dihadapi oleh siswa di SMK Negeri 1 Singosari program keahlian TOI. Kehidupan saat ini akan selalu terhubung dengan teknologi yang terus berkembang, yang membuat Revolusi Industri 4.0 memiliki dampak baik dan buruknya. Revolusi Industri akan berdampak baik dalam membantu dan mempermudah pekerjaan manusia, namun dalam hal lain sumber daya manusia semakin lama akan terganti oleh teknologi yang lebih modern. Siswa diharapkan memiliki berbagai kemampuan dalam menghadapi Revolusi Industri 4.0. Salah satu dari kemampuan tersebut yaitu kemampuan critical thinking. Kemampuan tersebut sangat dibutuhkan di abad 21 sebagai bekal siswa dalam menghadapi arus perubahan dari kemajuan teknologi.

Critical thinking pun menjadi salah satu life skill yang tengah dikembangkan dalam proses belajar mengajar. Melalui keahlian tersebut siswa dapat mencari solusi dalam pemecahan masalah yang dihadapi. Secara etimologi critical thinking memiliki arti kegiatan mental yang dilakukan seseorang dalam memberikan keputusan dengan dasar-dasar tertentu (Zubaidah, 2015). Ini yang membuat kemampuan critical thinking menjadi kemampuan yang mendasar untuk siswa lulusan SMK Teknik Otomasi Industri dalam menghadapi Revolusi Industri 4.0.

Menghadapi era Revolusi Industri 4.0 dibutuhkan Pendidikan yang mampu membentuk siswa yang lebih inovatif serta kreatif. Untuk menjamin keberhasilan pembelajaran siswa dalam menghadapi Revolusi Industri 4.0 siswa diwajibkan memiliki kemampuan dalam memahami perkembangan teknologi dan kemampuan berpikir kritis (Erdem \& Kinar. 2014). Kemampuan berpikir memiliki pengaruh penting dan harus dimiliki oleh siswa di setiap proses pembelajaran. Critical thinking merupakan kemampuan berpikir esensial yang dapat 
membantu siswa dalam menyelesaikan permasalahan dan persoalan dalam proses belajar. Kemampuan menyelesaikan masalah diharapkan dapat membantu siswa dalam mengasah kemampuan critical thinking nya dan mampu meningkatkan hasil belajar siswa. Kemampuan critical thinking dapat diimplementasikan pada penyelesaian masalah di kehidupan nyata dengan mencari tahu dan mempertimbangkan setiap keputusannya. Hal tersebut berdampak terhadap perkembangan pendidikan atau pola berpikir siswa ke arah berpikir kritis dan kemampuan tersebut sangat diperlukan pada mapel SKEE untuk kualitas yang baik dalam pembelajaran.

Alternatif solusi permasalahan pada penelitian ini yaitu penerapan Model Discovery Learning (DL) dan Model PBL. Pembelajaran discovery learning berfokus pada tantangan dan mampu meningkatkan pengalaman belajar, sehingga dapat digunakan untuk mengasah kemampuan critical thinking. Pembelajaran dengan basis permasalahan akan membuat siswa lebih siap dalam berpikir kritis dan analisis (Kurniawati et al., 2016). Model pembelajaran dengan karakteristik tersebut akan meningkatkan critical thinking siswa dengan memberikan kesempatan untuk menambah wawasan pengetahuan serta pengalaman dalam mencari ilmu.

Menurut (Sumitro et al., 2017) model pembelajaran yang mengarahkan siswa aktif dan meningkatkan kemampuan critical thinking adalah model pembelajaran problem based learning. Model PBL menerapkan sebuah permasalahan di sekitar dan bertujuan untuk meningkatkan cara berpikir kritis siswa dalam mengaitkan informasi yang didapatnya dengan menggabungkan dari pengetahuan yang dimilikinya. (Nafiah, 2014). Mengacu dari uraian permasalahan tersebut, peneliti membuat penelitian yang menerapkan model discovery learning dan PBL guna mengetahui signifikansi perbedaan antara kedua model pembelajaran tersebut terhadap critical thinking siswa. Oleh sebab itu, penelitian dilakukan dengan judul "Perbedaan Critical Thinking Sistem Kontrol Elektromekanik Dan Elektronik Menggunakan Model Pembelajaran Discovery Learning Dibandingkan Dengan Model Pembelajaran PBL Di Era Industri 4.0 Pada Siswa Kelas XI SMK Negeri 1 Singosari".

Berpikir kritis merupakan kebiasaan berpikir yang bisa dikembangkan oleh setiap orang. Hal ini menyebabkan kemampuan berpikir kritis menjadi sesuatu yang penting dengan membiasakan dan melatih mulai usia dini hingga dewasa. Menurut (Franco, 2017) keterampilan berpikir kritis dipilih sebagai alat penting untuk sukses di tempat kerja, namun banyak Lembaga Pendidikan yang kurang menyadari apa yang dicari di dunia kerja. Critical thinking adalah kegiatan yang terstruktur dalam membantu penyelesaian masalah, mengevaluasi, penemuan secara Ilmiah maupun pembuatan keputusan (Johnson, 2015). Sejalan dengan Johnson, menurut (Hendra ,2011) critical thinking memiliki arti yang sama dengan reflective thought yaitu berpikir secara gigih dan aktif dengan penuh pertimbangan secara cermat megenai sebuah kepastian atau ilmu yang didapatkan dari beberapa sumber ilmu yang nantinya bisa dijadikan sebagai dukungan atau sebuah kesimpulan.

Merujuk pada hasil penelitian yang usai dilakukan oleh sebagian peneliti yang selaras dengan perbandingan critical thinking dengan model pembelajaran PBL diantaranya telah dilakukan oleh (Lestari, 2018). Hasil dari critical thinking menunjukkan bahwa siswa yang menggunakan model PBL yang semula 59,84\% (rendah) menjadi 79,53\% (tinggi). Selanjutnya (Ma'rifah, 2019) melakukan penelitian yang berjudul "Perbedaan keterampilan berpikir kritis dan hasil belajar Biologi siswa pada pembelajaran PBL dan Think Pair Square". Hasil pengolahaan data penelitian ini mempunyai rata-rata keterampilan berpikir kritis dengan 71,2 
untuk model PBL dan 75,5 untuk model think pair square. Dari penelitian yang dilakukan oleh (Octaviana, 2018) dan (Ma'rifah, 2019) memiliki perbedaan. (Octaviana, 2018) melakukan penelitian di SMA Brawijaya Smart School Malang dengan mata pelajaran ekonomi. (Ma'rifah, 2019) melakukan penelitian dengan mata pelajaran biologi.

Hasil penelitian yang berkaitan dengan model pembelajaran Discovery Learning dan PBL yang telah dilakukan oleh (Ilmiah, 2016). Hasil pengolahan data dalam penilitian ini bahwa berdasarkan hasil analisis dekriptif diperoleh rata-rata nilai dari dua kelompok tersebut, yaitu kelas eksperimen 1 sebelum melakukan pretest sebesar 63,00 dan setelah melakukan posttest sebesar 81,70. Sedangkan pada kelas eksperimen 2 rata-rata pretest sebesar 55,80 dan ratarata posttest sebesar 80,00 .

Berdasarkan latar belakang masalah dan penelitian relevan penelitian ini memiliki tujuan: 1) Mendeskripsi critical thinking Sistem Kontrol Elektromekanik dan Elektronik aspek pengetahuan menerapakn model pembelajaran discovery learning siswa kelas XI Teknik Otomasi Industri di SMK Negeri 1 Singosari. 2) Mendeskrispsi critical thinking Sistem Kontrol Elektromekanik dan Elektronik aspek pengetahuan menerapkan model pembelajaran PBL siswa kelas XI Teknik Otomasi Industri di SMK Negeri 1 Singosari. 3) Mengetahui apakah ada perbedaan critical thinking Sistem Kontrol Elektromekanik dan Elektronik antara kelompok siswa yang menerapkan model pembelajaran discovery learning dibandingkan dengan kelompok siswa menerapkan model pembelajaran PBL siswa kelas XI Teknik Otomasi Industri di SMK Negeri 1 Singosari.

\section{Metode}

\subsection{Rancangan Penelitian}

Penelitian ini menerapkan penelitian eksperimen. Dengan mengkomparasi model pembelajaran. Tujuan penelitan ini adalah untuk melihat suatu perubahan ketika subjek telah diberi perlakuan. Sebelum melakukan eksperimen perlu diperhatikan desain eksperimennya. Selanjutnya desain tersebut akan menguji hipotesis dengan kesimpulan yang valid tentang hubungan antara variabel terikat dan variabel bebas.

Tabel 1. Rancangan Penelitian

\begin{tabular}{cll}
\hline Kelas & Perlakuan & Post Test \\
\hline A & 01 & Y1 \\
B & O2 & Y2 \\
\hline
\end{tabular}

Keterangan :

A : Kelompok eksperimen 1 (XI TOI 1) B : Kelompok eksperimen 2 (XI TOI 2)

01 :Perlakuan model pembelajaran discovery learning

$\mathrm{O} 2$ :Perlakuan model pembelajaran problem based learning

$\mathrm{Y} 1$ : Posttest kelas eksperimen A setelah pemberian perlakuan

Y2 : Posttest kelas eksperimen B setelah pemberian perlakuan

\subsection{Langkah - Langkah Penelitian}


Kegiatan proses pembelajaran pada kelas eksperimen dalam penelitian ini adalah sebagai berikut.

Tahap pertama, dilakukan pengamatan kelas untuk memahami atau memperoleh data tentang kondisi kelas dalam pembelajaran, jumlah siswa yang akan diteliti dalam penelitian ini, jadwal mata pelajaran, dan guru yang akan mendampingi dalam penelitian.

Tahap kedua, dilakukan eksperimen dengan cara memberikan treatment di setiap kelas berupa penerapan pembelajaran discovery learning untuk eksperimen A dan eksperimen B menerapkan problem based learning. Dalam pelaksanaan eksperimen maka faktor luar dari kedua kelas tersebut akan diperhatikan yakni waktu pelaksanaan dari kegiatan pembelajaran adalah sama namun berbeda hari, peralatan dan bahan ajar yang dipakai guru untuk mengajar dan siswa untuk praktikum adalah sama, serta secara fisik kelas yang digunakan adalah kelas yang setara baik dari segi ukuran, fasilitas dan kelengkapan kelas.

Tahap ketiga adalah pengukuran critical thinking kepada siswa dengan model discovery learning untuk kelas eksperimen A dan kelas eksperimen B menggunakan pembelajaran problem based learning.

Tahap keempat, adalah menganalisis data dari critical thinking kelas eksperimen A dan kelas eksperimen B setelah dilakukan pengambilan nilai untuk aspek pengetahuan dengan melihat hasil posttest.

Tahap kelima, adalah melihat apakah ada perbedaan critical thinking di aspek pengetahuan antara eksperimen A menggunakan Discovery Learning dan eksperimen B menggunakan pembelajaran Problem Based Learning.

\subsection{Populasi Dan Sampel}

\subsubsection{Populasi}

Menurut (Sugiyono, 2016) pengertian populasi merupakan obyek atau subyek yang ada di suatu wilayah dan mempunyai nilai karakteristik untuk dilakukannya penelitian guna mengambil sebuah kesimpulan. Penelitian ini populasi nya terdiri dari siswa kelas XI Teknik Otomasi Industri di SMKN 1 Singosari Kabupaten Malang. Dengan jumlah keseluruhan sis akelas XI TOI adalah 66 siswa. Disetiap kelasnya memiliki jumlah 33 siswa yang dibagi pada 2 kelas

Tabel 2. Data Keseluruhan Populasi

\begin{tabular}{cll}
\hline No. & Kelas & Jumlah Siswa \\
\hline 1. & Otomasi 1 & 33 \\
2. & Otomasi 2 & 33 \\
\hline
\end{tabular}

(Sumber: SMK Negeri 1 Singosari, Kabupaten Malang)

\subsubsection{Sampel}

Untuk sampel penelitian ini mengambil seluruh bagian dari populasi dikarenakan pada kelas XI Teknik Otomasi Industri terdapat 2 kelas. Sampel penelitian ini mengambil dua kelas dari jumlah populasi, dimana yang diambil adalah kelas otomasi 1 dengan 33 siswa dan kelas otomasi 2 dengan 33 siswa. 
Jurnal Inovasi Teknik dan Edukasi Teknologi (JITET), 1(1), 2021, 46-58

Tabel 3. Data Sampel

\begin{tabular}{cll}
\hline No. & Kelas & Jumlah Siswa \\
\hline 1. & Otomasi 1 & 33 \\
2. & Otomasi 2 & 33
\end{tabular}

(Sumber: SMK Negeri 1 Singosari, Kabupaten Malang)

\subsubsection{Instrumen Penelitian}

\subsubsection{Instrumen Perlakuan}

Instrumen perlakuan digunakan untuk instrumen dalam proses pembelajaran ketika di kelas kontrol dan kelas ekperimen. Instrumen ini terdiri dari:

a. Rencana Pelaksanaan Pembelajaran (RPP) RPP diberlakukan di kelas eksperimen. Penelitian ini menggunakan KD 3.11 Menentukan kondisi operasi kontaktor dan KD 4.11 Memeriksa kondisi operasi kontaktor. RPP digunakan pada penelitian ini sebagai rencana yang menggambarkan model discovery learning dibandingkan dengan model PBL mengenai kompetensi dasar yang dijabarkan dari silabus. RPP untuk kelas ekperimen model discovery Learning dan Problem Based Learning.

b. Bahan Ajar adalah sekumpulan informasi mengenai materi belajar yang akan dilakukan guru. Penelitian ini memakai bantuan bahan ajar yang nantinya digunakan pada saat kegiatan belajar mengajar. Bahan ajar yang digunakan meliputi: job sheet dan handout.

c. Handout adalah ringkasan dari berbagai sumber ilmu yang selaras dengan kompetensi dan materi yang akan diberikan kepada peserta didik (Prastowo, 2015). Handout menjadi pegangan oleh siswa untuk membantu siswa memahami materi. Handout Sistem Kontrol Elektromekanik dan Elektronik berisi cover, tujuan pembelajaran, materi pokok pembelajaran, serta tugas yang harus dikerjakan secara kelompok atau individu. Tahapan dalam membuat handout meliputi: menganalisis kurikulum yang menjadi acuan, yaitu kurikulum 2013 revisi 2018, menentukan judul handout berdasarkan pada kompetensi dasar dan materi pokok yang akan diajarkan, mengumpulkan referensi sebagai kevalidan materi, implementasi pembuatan handout, dan melakukan evaluasi terhadap handout yang telah dibuat.

d. Jobsheet merupakan bahan ajar yang terdiri dari latihan dan studi kasus. Bahan ajar ini digunakan ketika pembelajaran praktikum.

\subsubsection{Instrumen Pengukuran}

Hasil perlakuan ketika proses pembelajaran berlangsung dan hasil pembelajaran diukur dengan menggunakan instrumen pengukuran. Instrumen pengukuran digunakan untuk mengukur critical thinking siswa terhadap model yang digunakan guru dikelas. Instrumen ini terdiri dari:

a. Kisi-kisi Soal merupakan sekumpulan informasi yang digunakan sebagai pedoman dalam menyusun soal sesuai dengan materi. Syarat dalam pembuatan kisi-kisi soal mewakili isi kurikulum yang akan diujikan. Kisi-kisi soal bertujuan untuk mengukur pemahaman siswa terhadap materi yang telah diajarkan. 
b. Tes Tertulis, pada penelitian ini instrumen tes digunakan untuk mengetahui aspek pengetahuan siswa, yang mana kompetensi siswa dapat diketahui sesuai dengan pengetahuan siswa. Instrumen tes ini diberikan kepada siswa setelah guru menggunakan model pembelajaran. Tes ini dilakukan dengan memberikan tes objektif, pelaksanaan test dilakukan sesudah pembelajaran (posttest), kemudian pada pertemuan terakhir dilakukan tes secara keseluruhan dengan soal essay.

\subsubsection{Teknik Analisa Data}

Data itu dikumpulkan oleh sampel yang telah ditentukan sebelumnya. Sampel tersebut terdiri sekumpulan unit analisis sebagai sarana penelitian. Untuk tahap keseluruhan dalam penelitian ini meliputi tahap persiapan, pelaksanaan dan pengumpulan data.

a. Tahap persiapan, meliputi: a) menyusun instrumen penelitian; b) memvalidasi instrumen penelitian; c) mengurus surat ijin penelitian; d) melakukan uji coba skala kecil instrumen penelitian; e) mengolah dan menganalisis data hasil uji coba.

b. Tahap pelaksanaan, yakni: a) menganalisis hasil nilai dari KD sebelumnya; b) melaksanaan pembelajaran menggunakan model pembelajaran discovery learning dibandingkan dengan model pembelajaran problem based learning; c) memberikan Posttest pada kedua kelas.

c. Tahap terakhir dari penelitian ini adalah tahap pengumpulan data, sebagai berikut: a) mengumpulkan data critical thinking siswa aspek pengetahuan dari nilai posttest; $b$ ) menganalisis semua data nilai yang diperoleh dari kedua kelas dengan uji statistik.

\section{Hasil dan Pembahasan}

Untuk kelas eksperimen A diterapkan model pembelajaran Discovery Learning dan kelas eksperimen B diterapkan model pembelajaran Problem Based Learning. Data yang diteliti meliputi data critical thinking siswa aspek pengetahuan.

\subsection{Analisis Deskriptif Kelas Eksperimen A}

\subsubsection{Data Critical Thinking Awal Siswa Kelas Eksperimen A}

Data critical thinking awal siswa merupakan data yang diperoleh sebelum siswa diberi perlakuan. Kelas ekperimen A sebelum diberi perlakuan model pembelajaran discovery learning. Hasil critical thinking awal menunjukkan bahwa: (1) kategori frekuensi sangat rendah pada nilai interval 0 sampai 46,3 memperoleh persentase $24 \%$ dengan jumlah siswa 8. Selanjutnya kategori frekuensi rendah pada nilai interval ideal 46,4 sampai 57,1 memperoleh persentase $42 \%$ dengan jumlah siswa 14; (2) kategori tinggi dengan nilai interval 68 sampai 78,7 memperoleh persentase 10\% dengan jumlah 3 siswa. Sedangkan pada nilai sangat tinggi dengan interval 78,8 sampai 95 memperoleh persentase $0 \%$ artinya tidak ada siswa yang mendapatkan nilai dengan kategori sangat tinggi pada nilai sebelumnya. Nilai rata-rata pada KD sebelumnya diperoleh yaitu 53,9. Rata-rata tersebut apabila dikategorikan termasuk rendah. 


\subsubsection{Data Critical Thinking Akhir Siswa Eksperimen A}

Data critical thinking akhir siswa merupakan data yang diperoleh setelah siswa diberi perlakuan. Hasil critical thinking akhir menunjukkan bahwa: (1) kategori frekuensi nilai sangat tinggi dengan nilai interval 78,8 sampai 95 memperoleh presentasi 64\% dengan jumlah siswa 21; (2) nilai kategori tinggi interval ideal 68 sampai 78,7 memperoleh persentase $36 \%$ dengan jumlah 12 siswa; dan kategori lainnya sebanyak $0 \%$ artinya tidak ada siswa yang mendapat nilai dengan kategori sedang, rendah dan sangat rendah. Nilai rata-rata pada posttest diperoleh yaitu 80,76 . Rata- rata tersebut termasuk kedalam sangat tinggi.

\subsection{Analisis Deskriptif Kelas Eksperimen B}

\subsubsection{Data Critical Thinking Awal Siswa Kelas Eksperimen B}

Data critical thinking awal siswa merupakan data yang diperoleh sebelum siswa diberi perlakuan. Hasil critical thinking awal menunjukkan bahwa; (1) kategori frekuensi lapangan kategori rendah nilai interval ideal 46,4 sampai 57,1 memperoleh persentase 34\% dengan jumlah siswa 11. Selanjutnya kategori sangat rendah memperoleh persentase $30 \%$ dengan jumlah 10 siswa; (2) kategori tinggi pada nilai interval 68 sampai 78,7 memperoleh persentase $12 \%$ dengan jumlah siswa 4 dan kategori sangat tinggi pada nilai interval 78,8 sampai 95 memperoleh $0 \%$ artinya tidak ada siswa yang memperoleh nilai pada interval sangat tinggi. Nilai rata-rata pada KD sebelumnya memperoleh yaitu 53,5. Rata- rata tersebut apabila dikategorikan termasuk rendah.

\subsubsection{Data Critical Thinking Akhir Siswa Kelas Eksperimen B}

Data critical thinking akhir siswa merupakan data yang diperoleh setelah diberikannya perlakuan terhadap siswa. Kelas eksperimen B menggunakan model pembelajaran problem based learning. Hasil critical thinking akhir menunjukkan bahwa; (1) kategori nilai tinggi dengan nilai interval 68 sampai 78,7 memperoleh persentase 9\% dengan jumlah siswa 3; (2) kategori sangat tinggi dengan nilai interval ideal 78,8 sampai 95 memperoleh persentase $91 \%$. Siswa yang memperoleh pada kategori sangat tinggi berjumlah 30 siswa; dan katefori lainnya sebanyak $0 \%$ artinya tidak ada siswa yang memperoleh dengan kategori sangat rendah, rendah dan sedang. Nilai rata-rata pada posttest memperoleh 85,12 . Rata-rata tersebut termasuk kedalam kategori sangat tinggi.

\subsection{Analisis Uji Beda}

\subsubsection{Uji Prasyarat Analysis}

Uji Normalitas Data Critical Thinking Awal Siswa, Uji normalitas data dihitung dengan bantuan Software SPSS 21.0 for windows dengan metode Shapiro-Wilk. Hasil Normalitas critical thinking awal siswa kelas eksperimen A dan eksperimen B dapat dilihat pada Tabel 4. 
Jurnal Inovasi Teknik dan Edukasi Teknologi (JITET), 1(1), 2021, 46-58

Tabel 4. Hasil Uji Normalitas Data Critical Thinking Awal Siswa

\begin{tabular}{|c|c|c|c|}
\hline \multirow[t]{2}{*}{ Kelas } & \multicolumn{3}{|l|}{ Shapiro-Wilk } \\
\hline & Statistic & Df & Sig. \\
\hline Eksperimen A & 0,947 & 33 & 0,110 \\
\hline Eksperimen B & 0,966 & 33 & 0,376 \\
\hline
\end{tabular}

Uji Homogenitas Data Critical Thinking Awal Siswa. Hasil homogenitas data critical thinking awal siswa kelas eksperimen A dan eksperimen B menggunakan Software SPSS 21.0 for windows dengan metode Levene's dapat dilihat pada Tabel 4.6

Tabel 5. Hasil Uji Homogenitas Data Critical Thinking Awal Siswa

\begin{tabular}{cll}
\hline Kelas & Sig. & Keterangan \\
\hline Eksperimen A & 0,742 & Homogen \\
Eksperimen B & & \\
\hline
\end{tabular}

Uji Kesamaan Dua Rata-Rata Data Critical Thinking Awal Siswa. Hasil kesamaan dua rata-rata kemampuan awal siswa kelas eksperimen A dan kelas eksperimen B menggunakan Software SPSS 21.0 for dengan uji Independent Sample t Test dapat dilihat pada Tabel 4.7

Tabel 6. Hasil Uji Kesamaan Dua Rata- Rata Data Critical Thinking Awal

\begin{tabular}{lllllll}
\hline & & F & Sig. & T & Df & Sig.(2tailed) \\
\hline KD & Equal Variances assumed & 0,109 & 0,742 & $-0,177$ & 64 & 0,860 \\
3.10 & Equal variances not & & & - & 63,344 & 0,860 \\
& assumed & & & 0,177 & & \\
\hline
\end{tabular}

Uji Normalitas Data Critical Thinking Akhir Siswa. Hasil normalitas critical thinking akhir siswa kelas eksperimen A dan eksperimen B dapat dilihat pada Tabel 4.8

Tabel 6. Hasil Uji Normalitas Data Critical Thinking Akhir Siswa

\begin{tabular}{|c|c|c|c|}
\hline \multirow[t]{2}{*}{ Kelas } & \multicolumn{3}{|l|}{ Shapiro-Wilk } \\
\hline & Statistic & Df & Sig. \\
\hline Eksperimen A & 0,946 & 33 & 0,100 \\
\hline Eksperimen B & 0,936 & 33 & 0,051 \\
\hline
\end{tabular}

Uji Hipotesis Critical Thinking Siswa. Pengujian hipotesis terhadap data nilai critical thinking kedua kelas eksperimen. Uji hipotesis dilakukan dengan menggunakan bantuan Software SPSS 21.0 for windows menggunakan Independent Sampel t Test. Hipotesis yang diajukan adalah, Ho: Tidak terdapat perbedaan critical thinking sistem kontrol elektromekanik dan elektronik aspek pengetahuan menggunakan model pembelajaran discovery learning dibandingkan dengan model pembelajaran PBL siswa kelas XI di SMK Negeri 1 Singosari.

Deskripsi Data Critical Thinking Akhir Siswa dengan Model Pembelajaran Discovery Learning. Data critical thinking awal siswa adalah data yang diperoleh sebelum siswa diberi perlakuan. Dilihat dari nilai KD sebelumnya kelas eksperimen A menunjukkan rata-rata critical thinking awal siswa berada pada kategori rendah dengan nilai 53,09. 
Setelah diberikannya perlakuan pada kelas eksperimen A dengan model pembelajaran discovery learning menunjukkan kemampuan akhir siswa atau setelah diberikannya perlakuan, persentase tertinggi berada di katagori sangat tinggi menunjukkan persentase $64 \%$ dengan jumlah 21 siswa. Sehingga rata-rata critical thinking akhir siswa berada pada kategori sangat tinggi dengan nilai 80,76. Adanya peningkatan critical thinking pada kelas eksperimen A ini dikarenakan pemberian perlakuan yang menggunakan model pembelajaran Discovery Learning untuk meningkatkan kemampuan intelektual siswa, kemampuan siswa dalam menyelesaikan suatu masalah, siswa terlatih dalam mengkomunikasikan ide-ide dan mengembangkan karakter siswa yang sudah tersusun dalam langkah pembelajaran Pendekatan Saintifik. Menurut (Illahi, 2012) dalam penerapan discovery learning siswa akan merasakan pengalaman dalam belajar, selanjutnya siswa akan membentuk konsep pembelajaran dan menyerap semua materi dengan cara masing-masing siswa. Seseorang yang berhasil dalam belajarnya yaitu mampu menunjukkan adanya perubahan dalam dirinya. (Wahidmurni. 2010)

Hal tersebut sejalan dengan (Hosnan, 2014) menyatakan bahwa model pembelajaran discovery learning adalah pembelajaran yang mampu membantu siswa untuk memperbaiki dan meningkatan keterampilan dalam proses belajar kognitif siswa. Ketika siswa belajar mengambil keputusan siswa akan spontan menggunakan kemampuan berfikir kritis yang dimiliki. Hal tersebut terbukti pada saat penelitian di kelas, siswa belajar memberi solusi dari permasalahan yang dihadapinya. Model pembelajaran discovery learning akan mengarahkan siswa untuk berpikir secara kritis, dimana siswa akan diarahkan lebih aktif dalam mengidentifiksi permasalahan dengan pemahamannya pada saat proses belajar mengajar (Arindah. 2016). Kegiatan pembelajaran melibatkan secara maksimal seluruh kemampuan peserta didik untuk mencari dan menyelidiki secara sistematis, kritis dan logis sehingga mereka dapat menemukan sendiri pengetahuan, sikap dan kemampuan sebagai wujud adanya perubahan perilaku (Hanafia \& Suhana. 2012).

Pembelajaran discovery learning dimulai dengan memberikan stimulasi untuk peserta didik tentang materi yang akan dipelajari. Guru memunculkan ketertarikan siswa pada materi yang diberikan. Dengan memunculkan ketertarikan siswa terhadap suatu materi, siswa aktif dalam mencari tahu dan menjawab pertanyaan yang diberikan oleh guru. Penugasan dalam materi ini ditujukan agar siswa mencari dan menemukan hal baru tentang materi yang telah dipaparkan. Dengan penugasan ini siswa akan lebih meningkatkan berpikir kritisnya. Selanjutnya setelah penugasan, siswa menyampaikan hal yang telah didapat dari materi tersebut dengan cara mendemonstrasikan hasil pengamatan kemudian menyimpulkan hasil dari pengamatan. Untuk mengukur critical thinking, siswa mengerjakan soal posttest yang berbentuk essay di akhir pembelajaran.

Deskripsi Data Critical Thinking Akhir Siswa dengan Model Pembelajaran Problem Based Learning. Data critical thinking awal siswa adalah data yang diperoleh sebelum siswa diberi perlakuan. Dilihat dari nilai KD sebelumnya kelas eksperimen B menunjukkan rata-rata critical thinking awal siswa berada pada kategori rendah dengan nilai 53,55 yang termasuk dalam kriteria rendah. Hasil dari kelas eksperimen B setelah diberikannya perlakuan dengan model pembelajaran PBL menunjukkan critical thinking akhir yang meningkat. Rata-rata critical thinking tersebut meningkat. Data critical thinking awal dan data critical thinking akhir yang telah didapat sesuai dengan penelitian (Arini et al., 2016) yang menyatakan bahwa model PBL dapat meningkatkan pengetahuan siswa. 
Dengan menggunakan model PBL siswa akan terlatih dalam cara berpikir kritis, mengkonstruk pengetahuan, pembelajaran kolaborasi, dan pembelajaran mandiri. (Orozco \& Romelia, 2016). Menurut (Aziz et al., 2016) model PBL pada tahap mengidentifikasi masalah dan menganalisis ini dapat meningkatkan kemampuan berpikir kritis siswa, karena siswa dilatih untuk menghubngkan beberapa konsep yang telah didapatnya, yang kemudian siswa akan merumuskan untuk memecahkan permasalahan tersebut. (Woa et al., 2018) menjelaskan bahwa dalam penerapan model PBL ini berepengaruh terhadap kemampuan siswa dalam memecahkan permasalahan. Adanya peningkatan pada kelas eksperimen B ini dikarenakan pemberian perlakuan yang menggunakan model pembelajaran PBL untuk meningkatkan critical thinking siswa. Dalam model pembelajaran PBL siswa lebih terlatih dalam mengkomunikasikan ide-ide dan mengembangkan karakter siswa.

Pembahasan Perbedaan Critical Thinking Siswa dengan Model Pembelajaran Discovery Learning dan Model Pembelajaran Problem Based Learning. Analisis untuk menguji adanya sedikit perbedaan hasil data pemahaman konsep akhir siswa kelas eksperimen A dan eksperimen B dilakukan dengan uji t pada data pemahaman konsep akhir siswa kedua kelas. Hal ini bertujuan untuk mengetahui signifikansi perbedaan sehingga dapat dianalisis lebih lanjut. Hasil uji t menunjukkan sig (2-tailed) 0,000 kurang dari 0,05 yang artinya terdapat perbedaan yang signifikan pada hasil critical thinking aspek pengetahuan antara kelas eksperimen A dan eksperimen B.

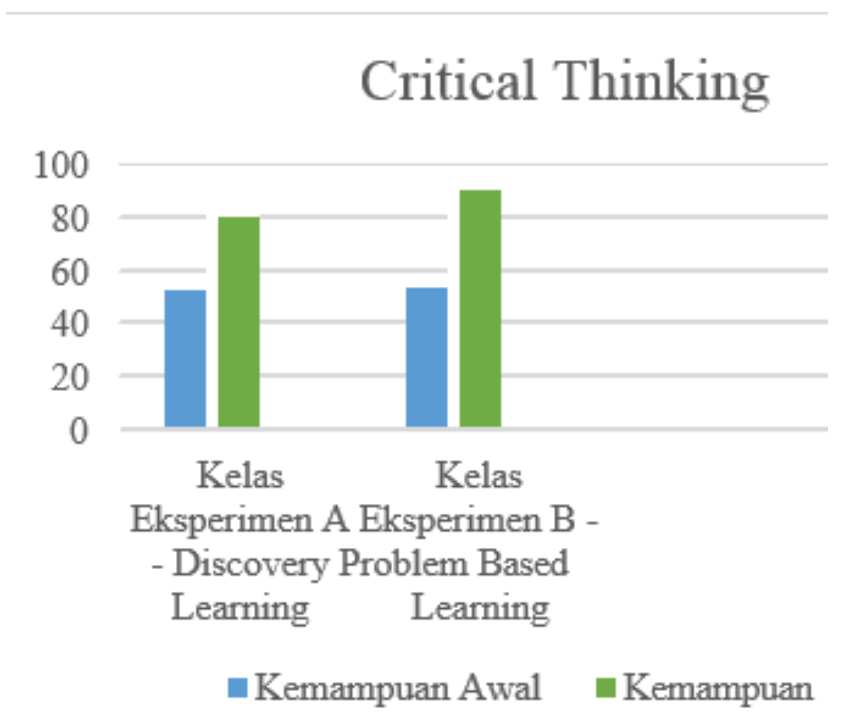

Beberapa alasan yang menyebabkan sedikitnya perbedaan data critical thiking akhir siswa, dikarenakan pada model pembelajaran discovery learning siswa tidak melakukan analisis mendalam terhadap masalah, sehingga tidak ada tahap menganalisis masalah seperti yang ada pada model pembelajaran problem based leaning. Siswa melakukan tahap indektifikasi masalah setelah melakukan tahap stimulation. Tahap stimulation melatih siswa untuk mengembangkan rasa ingin tahnya atau bereksplorasi. Siswa disajikan suatu permasalahan yang berkaitan dengan materi pembelajaran. Tahap selanjutnya dari model discovery learning yaitu identifikasi masalah. Pada tahap ini siswa dilatih untuk membuat atau merumuskan suatu permasalahan. Siswa menyampaikan permasalahan atau pertanyaan yang timbul terkait materi pembelajaran. Pertanyaan atau permasalahan yang timbul terebut akan membantu siswa menemukan dan memahami konsep yang dipelajari. 
Pembelajaran biasa (konvensional) jelas tidak buruk sehingga tidak harus dibuang, akan tetapi membuat siswa kurang unggul dalam kemampuan berpikir kritis dan sering membuat siswa kesulitan dalam memahami materi pembelajaran. Oleh karena itu (Hosnan, 2014) mengusulkan DL yang merupakan pembelajaran inovatif untuk mengatasi kelemahan dalam model pembelajaran.

Model pembelajaran PBL adalah pembelajaran yang memiliki sifat konstruktivisme dengan siswa diberi kesempatan untuk mendapatkan dan mencari ilmunya sendiri. Meskipun kedua model tersebut memiliki sifat konstruktivisme tetapi keduanya memiliki tahapan pembelajaran berbeda. Untuk PBL sendiri lebih berorientasi kepada masalah, sehingga pada tahapan pembelajaran siswa diwajibkan untuk memecahkan permasalahan. Berbeda dengan model discovery learning yang memiliki tujuan untuk memberikan pemahaman kepada peserta didik. Ini yang membuat PBL lebih unggul dengan memfasilitasi peserta didik dengan cara memberikan permasalahan yang nantinya siswa akan membuat pemahaman konsep untuk dirinya sendiri.

Kemampuan berpikir kritis merupakan potensi intelektual yang dapat dikembangkan melalui proses pembelajaran (Zubaidah, 2010). Kemampuan critical thinking berdasarkan Taksonomi Bloom mengharuskan siswa untuk mempunyai kemampuan menganalisis, sintesis dan mengevaluasi dalam suatu permasalahan. Siswa akan dilatih untuk menyelesaikan suatu permasalahan yang berkaitan dengan.

\section{Simpulan}

Berdasarkan hasil penelitian dan analisis data yang dilakukan maka dapat ditarik kesimpulan, berdasarkan deskripsi critical thinking penerapan model Discovery Learning pada kelas eksperimen A, terdapat peningkatan nilai yang dapat dilihat berdasarkan rerata nilai sebelumnya dan posttest critical thinking. Siswa memiliki rerata nilai sebelumnya yang termasuk kedalam kategori rendah. Setelah diterapkan model Discovery Learning nilai critical thinking siswa mengalami peningkatan dan termasuk kedalam kategori sangat tinggi. Penerapan model Discovery Learning cocok digunakan untuk meningkatkan critical thinking siswa karena siswa menemukan pola belajar dengan caranya sendiri. Berdasarkan deskripsi critical thinking penerapan model PBL pada kelas eksperimen B menunjukkan adanya peningkatan pada nilai rerata critical thinking. Pada rerata nilai sebelumnya siswa memiliki hasil nilai yang berada dalam kategori rendah. Setelah siswa diberi penerapan model PBL hasil posttest mengalami kenaikan dan termasuk kedalam kategori sangat tinggi. Model PBL memberikan permasalahan yang harus dipecahkan siswa. Yang mengakibatkan siswa akan menyelesaikan permsalahan sesuai dengan batasan lingkup permasalahan. Terdapat perbedaan critical thinking yang signifikan antara kedua kelas eksperimen setelah diberi penerapan model Discovery Learning dan Problem Based Learning. Kelas eksperimen B critical thinking pada materi pembelajaran. Pada proses belajar mengajar juga membutuhkan bantuan handout. Tujuan penggunaan handout atau lembar kerja siswa ini adalah memudahkan siswa untuk mengumpulkan informasi yang berkesinambungan dengan materi pembelajaran serta mempermudah siswa dalam memahami konsep pembelajaran dan meningkatkan cara bepikir kritis siswa (Prastowo, 2015) dengan PBL lebih unggul dari kelas eksperimen A dengan model discovery learning. Terlihat dari nilai posttest critical thinking kelas eskperimen B yang lebih tinggi dibandingkan dengan kelas eksperimen $\mathrm{A}$.

\section{Daftar Rujukan}




\section{Jurnal Inovasi Teknik dan Edukasi Teknologi (JITET), 1(1), 2021, 46-58}

Novita, L., Windiyani, T., \& Sakinah, A. R. (2020). Pengaruh Penerapan Model Discovery Learning Terhadap Hasil Belajar Matematika Siswa. Widyagogik: Jurnal Pendidikan dan Pembelajaran Sekolah Dasar, 7(2), 148-163.

Yuliantari, N. P. E., Wiarta, I. W., \& Abadi, I. B. G. S. (2016). Penerapan Model Problem Based Learning Dapat Meningkatkan Keaktifan Dan Penguasaan Kompetensi Pengetahuan Matematika Siswa. MIMBAR PGSD Undiksha, 4(1).

Aziz, A., Ahyan, S., \& Fauzi, L. M. (2016). Implementasi model Problem Based Learning (PBL) dalam meningkatkan kemampuan berpikir kritis mahasiswa melalui Lesson Study. Jurnal Elemen, 2(1), 83-91.

Erdem, M., \& Kibar, P. N. (2014). Students' Opinions on Facebook Supported Blended Learning Environment. Turkish Online Journal of Educational Technology-TOJET, 13(1), 199-206.

Franco, A. R., Costa, P. S., \& Almeida, L. S. (2017). Do critical thinkers drink too much alcohol, forget to do class assignments, or cheat on exams? Using a critical thinking measure to predict college students' realworld outcomes. Psychological Studies, 62(2), 178-187.

Hanafiah, N., \& Suhana, C. (2009). Konsep strategi pembelajaran. Bandung: Refika Aditama.

Surya, H. (2013). Strategi jitu mencapai kesuksesan belajar. Elex Media Komputindo.

Hosnan, M. (2014). Pendekatan saintifik dan kontekstual dalam pembelajaran abad 21: Kunci sukses implementasi kurikulum 2013.

Illahi, M. T. (2012). Pembelajaran discovery strategy \& mental vocational skill. Yogyakarta: Pustaka Pelajar.

Ilmiah, I. (2016). Tarbiyah dan Keguruan/Pendidikan Matematika Perbandingan Model Pembelajaran Discovery Learning (DL) dan Problem Based Learning (PBL) Berbasis Assesment for Learing (AFL) terhadap Hasil Belajar Matematika Siswa Kelas VII SMP AL Mazaakhriah Baramuli Kab. Pinrang (Doctoral dissertation, Universitas Islam Negeri Alauddin Makassar).

Johnson, S., \& Siegel, H. (2010). Teaching thinking skills. Bloomsbury Publishing.

Kurniawati, D. (2010). Upaya Meningkatkan Kemandirian Belajar Siswa dalam Pembelajaran Matematika Melalui Model Cooperative Learning Tipe Kepala Bernomor Terstruktur pada Siswa SMP N 2 Sewon Bantul. Skripsi Tidak Dipublikasikan, Universitas Negeri Yogyakarta.

Lestari, O. K. (2018). Perbandingan peningkatan critical thinking skills siswa melalui model pembelajaran cooperative script dan Problem Based Learning (PBL) pada mata pelajaran ekonomi kelas XI IIS SMA Brawijaya Smart School Malang (Doctoral dissertation, Universitas Negeri Malang).

Nafiah, Y. N., \& Suyanto, W. (2014). Penerapan model problem-based learning untuk meningkatkan keterampilan berpikir kritis dan hasil belajar siswa. Jurnal Pendidikan Vokasi, 4(1).

Orozco, J. A., \& Yangco, R. T. (2016). Problem-based learning: effects on critical and creative thinking skills in biology. Asian Journal of Biology Education Vol, 9(3).

Prastowo, A. (2011). Panduan kreatif membuat bahan ajar inovatif..

Yani, A., Mangkunegara, A. A. P., Revisi, P. K. E., \& Aditama, R. Sugiyono. 2011. Metode Penelitian Kuantitatif Kualitatif dan R\&D. Bandung: Alfabeta.

Setyosari, P., \& Sumarmi, S. (2017). Penerapan model problem-based learning meningkatkan motivasi dan hasil belajar IPS. Jurnal Pendidikan: Teori, Penelitian, dan Pengembangan, 2(9), 1188-1195.

Wahidmurni, A. M., \& Ridho, A. (2010). Evaluasi Pembelajaran: Kompetensi dan Praktik. Yogyakarta: Nuha Letera.

Woa, K. M., Utaya, S., \& Susilo, S. (2018). Pengaruh Model Pembelajaran Problem Based Learning terhadap Kemampuan Memecahkan Masalah Geografi pada Siswa SMA. Jurnal Pendidikan: Teori, Penelitian, dan Pengembangan, 3(3), 406-411.

Arifin, Z. (2017). Mengembangkan instrumen pengukur critical thinking skills siswa pada pembelajaran matematika abad 21. Jurnal THEOREMS (The Original Research of Mathematics), 1(2).

Zubaidah, S. (2010, January). Berpikir Kritis: kemampuan berpikir tingkat tinggi yang dapat dikembangkan melalui pembelajaran sains. In Makalah Seminar Nasional Sains dengan Tema Optimalisasi Sains untuk memberdayakan Manusia. Pascasarjana Unesa (Vol. 16, pp. 1-14). 